\title{
Neurotrophin 4 Is Required for the Survival of a Subclass of Hair Follicle Receptors
}

\author{
Cheryl L. Stucky, ${ }^{1}$ Thomas DeChiara, ${ }^{2}$ Ronald M. Lindsay, ${ }^{2}$ George D. Yancopoulos, ${ }^{2}$ and \\ Martin Koltzenburg ${ }^{1}$ \\ ${ }^{1}$ Department of Neurology, University of Würzburg, D-97080 Würzburg, Germany, and 2Regeneron Pharmaceuticals, \\ Tarrytown, New York 10591
}

Neurotrophin-4 (NT4) is the most recently discovered neurotrophic factor in mammals and, functionally, the least well understood. Here, we used mice that lack NT4 to determine whether NT4 is required for the survival of functionally identified subclasses of cutaneous sensory neurons. By using three independent methods of histological and electrophysiological analysis, we show that NT4 is specifically required for the survival of down hair (D-hair) receptors that innervate a subpopulation of hair follicles. All other functionally distinct types of afferents neurons innervating hairy skin were not affected in their survival or in their function. Previous studies have shown that BDNF is required for the mechanical sensitivity of slowly adapting (SA) mechanoreceptors but not for the postnatal survival of myelinated cutaneous afferent fibers. In contrast, the receptive properties of SA mechanoreceptors were not impaired in animals lacking NT4. Consequently, these data show that the two trkB ligands, NT4 and BDNF, have distinct and nonoverlapping roles in supporting cutaneous sensory neurons. Whereas NT4 is required for the survival of $D$-hair receptors, BDNF supports the mechanical function of SA fibers.

Key Words: NT4; brain-derived neurotrophin factor; NT3 (neurotrophin 3) wild-type mice; D-hair; skin innervation
Sensory neurons in the dorsal root ganglia depend on multiple neurotrophic factors throughout development for their survival and eventual differentiation into functional subtypes. Very early in development, neurotrophin 3 (NT3) regulates the proliferation of dorsal root ganglion precursor cells. As neurons begin to send processes to peripheral targets, either brain-derived neurotrophic factor (BDNF) or nerve growth factor (NGF) can support the survival of the majority of the neurons (Davies, 1997). Later, as sensory neurons differentiate into subtypes that subserve specific sensory modalities, they depend on particular neurotrophins (Lewin and Barde, 1996).

A series of recent studies has led to the concept that each of the neurotrophins has a specific role in regulating different classes of functionally identified sensory neurons. For example, NGF, signaling through its high-affinity receptor trkA, supports the survival of nociceptive sensory neurons (Crowley et al., 1994; Smeyne et al., 1994), whereas NT3 and trkC are required for the survival of non-nociceptive proprioceptors, muscle afferent fibers, and cutaneous mechanoreceptors (Ernfors et al., 1994b; Fariñas et al., 1994; Klein et al., 1994; Airaksinen et al., 1996). Animals lacking BDNF have been shown to reduce numbers of dorsal root ganglion neurons (Ernfors et al., 1994a), although it is unclear which subpopulations of neurons are lost. Moreover, BDNF has been shown to be essential for normal mechanical sensitivity of some low threshold mechanoreceptors (Carroll et al., 1998).

Neurotrophin 4 (NT4) is the most recently discovered member

Received Feb. 10, 1998; revised June 18, 1998; accepted June 23, 1998.

This work was supported by the Deutsche Forschungsgemeinschaft, Sonderforschungsbereich 353. We thank Dr. Ilka Bergmann for expert assistance with the confocal imaging and Dr. Gary Lewin for helpful discussions.

Correspondence should be addressed to Dr. Martin Koltzenburg, Department of Neurology, University of Würzburg, Josef-Schneider-Strasse 11, D-97080 Würzburg, Germany. Email: koltzenburg@mail.uni-wuerzburg.de

Copyright (C) 1998 Society for Neuroscience $0270-6474 / 98 / 187040-07 \$ 05.00 / 0$ of the family of neurotrophic factors that regulate the survival and differentiation of vertebrate neurons (Berkemeier et al., 1991; Hallböök et al., 1991; Ip et al., 1992). Although NT4 is the most ubiquitously expressed neurotrophin, it is functionally the least well understood (Ibáñez, 1996), and little is known about the role of NT4 in supporting the survival of identified classes of sensory neurons. Currently, the only available data are from cell counts of whole sensory ganglia. Mice lacking NT4 (NT4-/-) exhibit a loss of $\sim 50 \%$ of the neurons in the nodose-petrosal and geniculate ganglia but no apparent loss of neurons in the dorsal root ganglia (Conover et al., 1995; Liu et al., 1995; Erickson et al., 1996). However, no studies have addressed whether NT4 supports the survival or function of identified subclasses of dorsal root ganglion neurons that innervate a specific target. Furthermore, because NT4 and BDNF apparently both signal via the same high-affinity trkB receptor (Ip et al., 1993; Barbacid, 1994), a logical question is whether mice deficient in NT4 show the same sensory deficits as mice lacking BDNF. Therefore, we used an in vitro preparation of the saphenous nerve, a purely cutaneous nerve, along with the skin it innervates to determine whether cutaneous sensory neurons in adult NT4 $-/-$ mice are altered in either survival or function.

\section{MATERIALS AND METHODS}

Generation of mice. Adult mice lacking NT4 (NT4-/-) were generated as described previously (Conover et al., 1995). Briefly, 129/Ola embryonic stem (ES) cells were electroporated with a targeting vector in which the NT4 coding region was disrupted. Positive ES clones were microinjected into $\mathrm{C} 57 / \mathrm{B} 16$ mouse embryos and found to contribute to the germ line of chimeric mice. The $F_{1}$ generation heterozygotes were mated to produce $\mathrm{F}_{2}$ homozygotes. NT4-/- homozygotes were then mated for use in this study. Adult C57Bl6 mice were used as the wild-type (WT) controls throughout the study.

Nerve histology. A segment of saphenous nerve was removed at midthigh level from adult NT4-/- mice $(n=4)$ and WT controls $(n=4)$. Nerve segments were fixed in $2.5 \%$ glutaraldehyde and embedded in 
Epon. Semithin cross-sections of nerve were cut and stained with toluidine blue. All myelinated axon profiles were drawn with the aid of a camera lucida by an experimenter who was blind to the identity of the tissue on the slides. Drawings were subsequently scanned into computer files using a scanner (Scanmaster 3+; MWG-Biotech) and Picture Publisher 4.0 software. Using the NIH Image 1.59 analysis program, all profiles were counted and measured to give the mean axon diameter.

Innervation of hair follicles. Sections of depilated skin $(5 \times 5 \mathrm{~mm})$ were removed from the middle of the back of NT4-/ $(n=6)$ and WT mice $(n=5)$. The tissue was embedded in Tissue-Tec (Diatec) and frozen in liquid nitrogen. Transverse sections of skin $(60 \mu \mathrm{m}$ thick) were cut using a cryostat. Sections were fixed for $10 \mathrm{~min}$ in acetone at $-20^{\circ} \mathrm{C}$ and air-dried. Nonspecific binding sites were preabsorbed with $10 \%$ normal goat serum (Dako) in $0.1 \mathrm{M}$ PBS, pH 7.4, for $30 \mathrm{~min}$. Tissue sections were incubated overnight at room temperature with a polyclonal rabbit antiserum against neurofilament $\mathrm{H}$ (NA 1121; Affiniti; dilution, 1:500). NA 1211 staining was visualized by incubating tissue with fluorescein (FITC)-conjugated goat anti-rabbit IgG (1:100) for $2 \mathrm{hr}$ at room temperature. Six nonadjacent sections of tissue were analyzed from each animal by an experimenter who was blind to the identity of the tissue on the slides. The number of down (vellus) hair follicles per millimeter of epidermis were counted as well as the number of hair follicles innervated by myelinated fibers. A hair follicle was considered to be innervated by a myelinated fiber if it was encircled one or more times by a neurofilamentpositive fiber.

Neurophysiological recordings. We used the in vitro skin nerve preparation described previously (Koltzenburg et al., 1997; Stucky and Koltzenburg, 1997) to record from single, functionally identified cutaneous sensory neurons in the saphenous nerve of NT4-/ $(n=24)$ and WT $(n=13)$ mice. This nerve innervates the anterior and medial part of the leg and the medial portion of the dorsum of the paw (Koltzenburg et al., 1997). Therefore, we dissected the skin from this region of the hindlimb together with the saphenous nerve and placed the tissue corium side up in a tissue bath and superfused $(15 \mathrm{ml} / \mathrm{min})$ the skin with oxygensaturated, synthetic interstitial fluid containing (in $\mathrm{mM}$ ): $123 \mathrm{NaCl}, 3.5$ $\mathrm{KCl}, 0.7 \mathrm{MgSO}_{4}, 1.7 \mathrm{NaH}_{2} \mathrm{PO} 4,2.0 \mathrm{CaCl}_{2}$, 9.5 sodium gluconate, 5.5 glucose, 7.5 sucrose, and $10 \mathrm{HEPES}, \mathrm{pH} 7.45 \pm 0.05$, at $32 \pm 0.5^{\circ} \mathrm{C}$.

Single afferent fibers were recorded extracellularly from the desheathed nerve using gold wire electrodes. Action potentials were acquired using a low-noise differential amplifier, stored on a PC, and later analyzed with a template-matching program (Forster and Handwerker, 1990). Fibers were first identified by manual probing with a glass rod. Next, the conduction velocity of each mechanosensitive fiber was determined by electrically stimulating the receptive field with supramaximal square-wave pulses of $0.1-1.0 \mathrm{msec}$ duration using a Teflon-coated steel electrode (1-5 M $\Omega$ impedance; shaft diameter, $300 \mu \mathrm{m}$; uninsulated tip diameter, 5-10 $\mu \mathrm{m})$. Based on the distribution of conduction velocities of individual fibers previously recorded in control mice in this preparation, we classified units conducting faster than $10 \mathrm{~m} / \mathrm{sec}$ as large myelinated $(\mathrm{A} \beta-)$ fibers, units conducting between 1.2 and $10 \mathrm{~m} / \mathrm{sec}$ as thin myelinated (A $\delta-$ ) fibers, and units conducting slower than $1.2 \mathrm{~m} / \mathrm{sec}$ as unmyelinated (C-) fibers (Koltzenburg et al., 1997). Mechanical sensitivity was determined by using calibrated von Frey filaments (tip diameter, $0.8 \mathrm{~mm}$; range of force, 1-362 mN) and sustained force stimuli (200 msec rise time; $10 \mathrm{sec}$ duration of force plateau; range of force, 5-300 mN) applied by a computer-driven, feedback-controlled stimulator. Data were analyzed for $11 \mathrm{sec}$ beginning with the onset of force.

Myelinated fibers were classified as described previously into four subpopulations (Koltzenburg et al., 1997; Stucky and Koltzenburg, 1997). Large myelinated ( $\mathrm{A} \beta-$ ) fibers had low mechanical thresholds and were classified as either slowly adapting (SA) if they responded tonically to sustained force or rapidly adapting (RA) if they responded only at the onset or offset of force. SA fibers innervate the Merkel cell complexes in the touch domes, whereas RA fibers (also known as G-hair receptors) innervate tylotrich and guard hairs (Willis and Coggeshall, 1991; Light and Perl, 1993). Thin myelinated (A $\delta-$ ) fibers were classified as either A-fiber mechanonociceptors (AM) if they responded tonically to highintensity force or down hair (D-hair) receptors if they were activated by very low mechanical force $(<1 \mathrm{mN})$ and responded with high frequency to the onset and offset of force. Although the detailed morphological structure of D-hair receptors is not known (Light and Perl, 1993), they are thought to innervate down (vellus) hairs (Munger and Ide, 1988).

Unmyelinated C-fibers were tested for their response properties to mechanical stimuli and then further classified by their response properties to noxious thermal stimuli. Heat sensitivity was determined by
A
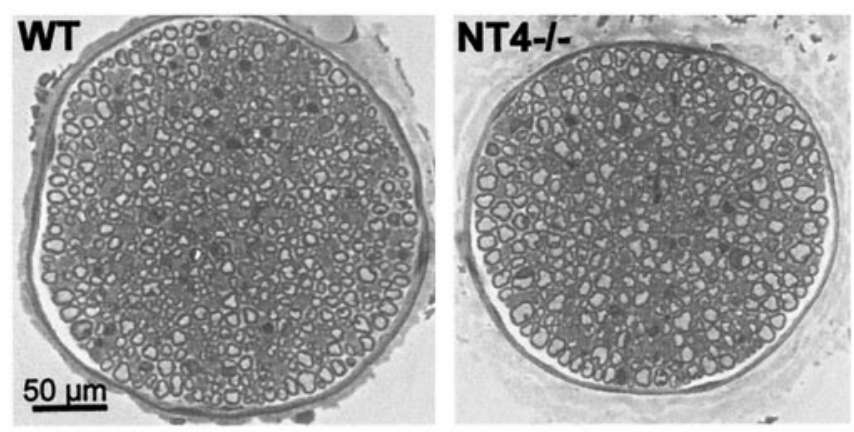

B

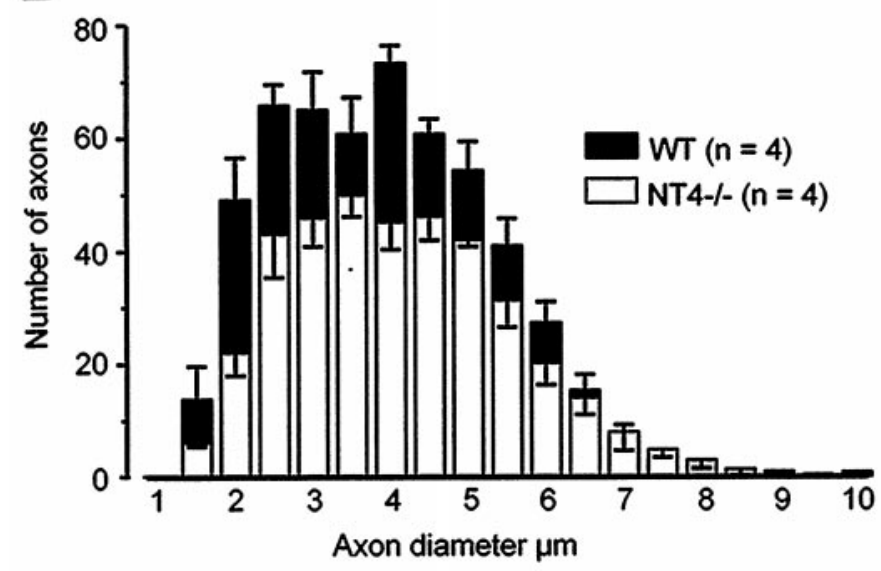

Figure 1. Distribution of myelinated fibers in the saphenous nerve by axon diameter. $A$, Cross-section of the saphenous nerve at mid-thigh level taken from wild-type animals (WT) and mice lacking NT4 (NT4-/-). Although the nerve is smaller in the knock-out animals, there is a preponderance of large myelinated axons. $B$, Mean histograms were generated from four WT and four NT4 $-/-$ mice. There was a significant loss in the total number of myelinated axons in NT4-/- mice compared with WT mice $(p<0.001, t$ test). Furthermore, the loss occurred among axons $<5.0 \mu \mathrm{m}$ in diameter $(p<0.005, t$ test) but not among axons $\geq 5.0$ $\mu \mathrm{m}$ in diameter $(p>0.1, t$ test $)$.

applying a feedback-coupled, linear heat ramp $\left(32-47^{\circ} \mathrm{C}\right.$ in $\left.15 \mathrm{sec}\right)$ with a lamp focused through the translucent bottom of the tissue bath onto the epidermal side of the skin, and actual temperature was measured at the corium side by a thermocouple inserted into the skin. A fiber was considered heat-sensitive if three or more action potentials were evoked during the stimulation.

Statistics. All values are given as mean \pm SEM or as median and the interquartile range of the 25 th -75 th percentile. Statistical analysis was performed using $t$ test, ANOVA, and $U$ test after fulfillment of necessary prerequisites using the Statistica software package (StatSoft, Tulsa, OK).

\section{RESULTS}

\section{Small-diameter myelinated fibers are preferentially lost in NT4-I- mice}

Figure $1 A$ illustrates that the saphenous nerve from an NT4-/animal is smaller than the saphenous nerve from a WT control. Counts of myelinated axons in the saphenous nerve revealed that there was a $29 \%$ loss in the total number of myelinated axons in NT4-/- mice (Fig. 1; WT, $543 \pm 18$; NT4-/-, $386 \pm 13 ; p<$ $0.001, t$ test). Specifically, the loss occurred among the smalldiameter myelinated axons. Note the absence of small myelinated 
profiles in the nerve from the NT4-/- animal. A previous report has shown that in mice, myelinated axons $>5 \mu \mathrm{m}$ in diameter correspond to large myelinated $(\mathrm{A} \beta-)$ fibers, whereas axons $<5$ $\mu \mathrm{m}$ in diameter are thin myelinated $(\mathrm{A} \delta-$ ) fibers (Airaksinen et al., 1996). Among axons with diameters $<5.0 \mu \mathrm{m}$, there was a $33 \%$ loss in NT4 $-/-$ mice $(260 \pm 29)$ compared with WT mice $(391 \pm 21 ; p<0.005, t$ test $)$, but among axons with diameters $\geq 5.0 \mu \mathrm{m}$, there was no significant loss (NT4-/- mice, $126 \pm 18$; $\mathrm{WT}, 151 \pm 8 ; p>0.1, t$ test).

\section{D-hair receptors in NT4-/- mice are lost}

Next, we determined whether the small-diameter myelinated fibers that were lost in NT4-/- animals were of a particular functional type. In the in vitro skin nerve preparation used here, thin myelinated A $\delta$ fibers (conduction velocities $<10 \mathrm{~m} / \mathrm{sec}$ ) are either D-hair receptors, which probably innervate down (vellus) hair follicles and respond phasically to very low-threshold stimuli $(<1 \mathrm{mN})$, or AM nociceptors, which have free nerve endings and respond tonically to high-threshold stimuli (Koltzenburg et al., 1997; Stucky and Koltzenburg, 1997). Electrophysiological analysis revealed that D-hair receptors were almost completely lost, because only $4 \%$ of thin myelinated fibers in NT4-/ - mice were D-hair receptors compared with $35 \%$ in WT mice $\left(p<0.001, \chi^{2}\right.$ test; Fig. 2A). Moreover, the two D-hair afferents found in NT4-/- mice had atypical response properties in that their mean conduction velocity $(8.2 \mathrm{~m} / \mathrm{sec})$ was significantly faster than that of D-hair receptors in WT mice $(4.8 \pm 0.4 \mathrm{~m} / \mathrm{sec} ; p<0.01$, $t$ test), and their responsiveness to mechanical stimuli was markedly reduced (Fig. 2B). Conversely, AM fibers, which made up the remainder of the thin myelinated fiber population in NT4-/mice, were normal in mechanical sensitivity, because their von Frey thresholds (median, $4.0 \mathrm{mN}$; interquartile range, $2.8 \mathrm{mN}$ ) were not different from the von Frey thresholds of AM fibers in WT controls (median, $5.6 \mathrm{mN}$; interquartile range, $5.2 \mathrm{mN} ; p>$ $0.1, U$ test). Because D-hair receptors make up $35 \%$ of the small-diameter myelinated (A $\delta)$ population in WT mice, a near complete loss in functional D-hair receptors accounts for the $33 \%$ loss in small-diameter myelinated axons in the saphenous nerve of NT4-/- mice. Together, our physiological and morphological data indicate that D-hair receptors are nearly absent in adult NT4-/- mice.

\section{Slowly adapting $A \beta$ fibers in NT4-/- mice are normal}

In contrast to SA fibers in mice lacking BDNF, SA fibers in NT4-/- mice were completely normal in both prevalence and mechanical responsiveness. Fifty percent of A $\beta$ fibers in NT4-/mice were SA, and $48 \%$ of $\mathrm{A} \beta$ fibers in WT mice were SA $(p>$ $0.5, \chi^{2}$ test; Fig. $3 A$ ). The remaining $\mathrm{A} \beta$ fibers in both groups were RA. The mechanical sensitivity and responsiveness of SA fibers in NT4-/- mice were completely normal, because the von Frey thresholds of SA fibers in NT4-/- mice (median, $1.0 \mathrm{mN}$; interquartile range, $0.4 \mathrm{mN}$ ) were not different from those in WT mice (median, $1.0 \mathrm{mN}$; interquartile range, $0.0 \mathrm{mN} ; p>0.5, U$ test), and the mean stimulus-response functions of SA fibers in NT4-/- mice were parallel to those of WT mice (Fig. $3 B$ ).

In addition, $\mathrm{C}$-fibers in NT4-/- mice were not different from $\mathrm{C}$-fibers in WT mice in their mechanical sensitivity (von Frey thresholds: NT4-/-, median, $5.6 \mathrm{mN}$; interquartile range, 4.0 $\mathrm{mN}$; WT, median, $5.6 \mathrm{mN}$; interquartile range, $7.2 \mathrm{mN} ; p>0.5$, $U$ test). Furthermore, the heat sensitivity of C-fibers was not different, because $50 \%(n=22)$ of C-fibers in NT4-/- mice responded to heat compared with $42 \%(n=19)$ of $\mathrm{C}$-fibers in

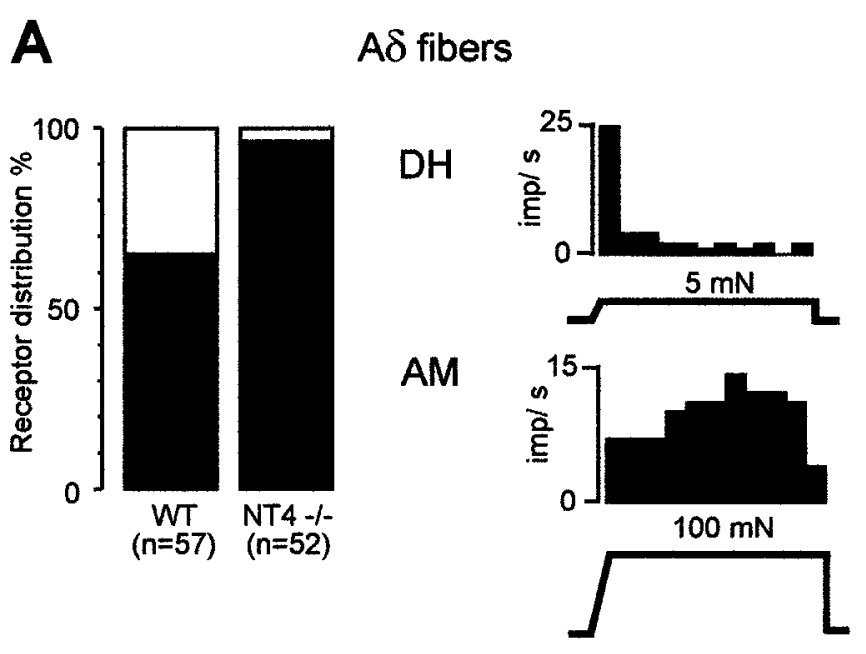

B D-hair receptors

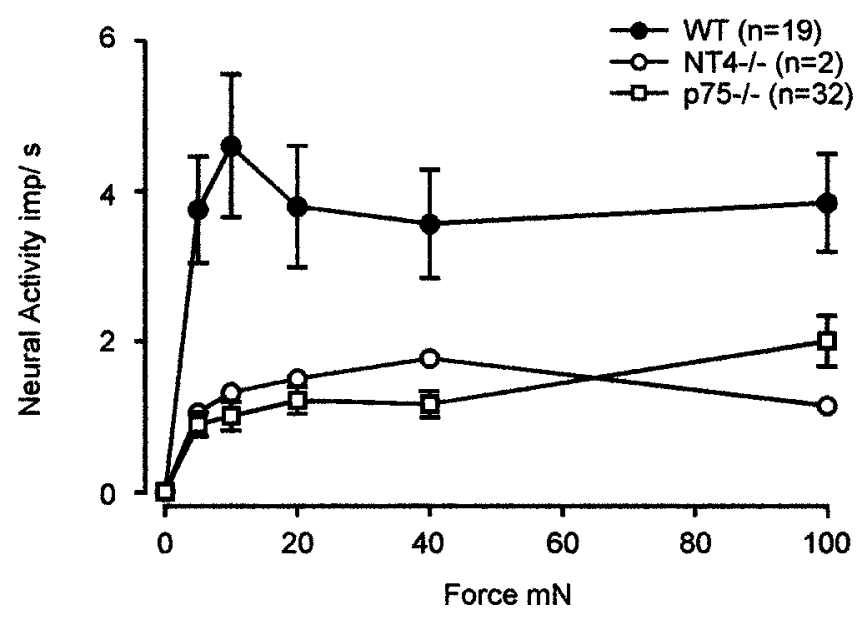

Figure 2. A, Left, Prevalence of subtypes of thin myelinated (A $\left.\delta^{-}\right)$ cutaneous fibers in WT and NT4- -1 mice that is significantly different $\left(p<0.001, \chi^{2}\right.$ test). Right, Histograms illustrate representative examples of the mechanical response properties of a D-hair receptor $(\mathrm{DH}, \mathrm{top})$ and an AM nociceptor $(A M$, bottom $) . B$, Stimulus-response functions of $\mathrm{D}$-hair receptors to constant force stimuli. The stimulus-response functions of the two D-hair receptors found in NT4-/- mice were reduced compared with WT mice $\left(F_{(1,103)}=6.21 ; p<0.05\right.$, ANOVA $)$ and closely resemble the stimulus-response functions of D-hairs in p75-/- mice (p75-/- data from Stucky and Koltzenburg, 1997).

WT mice ( $p>0.5, \chi^{2}$ test). Among heat-sensitive fibers, neither the average number of action potentials evoked per stimulus nor the threshold for a response was different in NT4-/- mice $\left(32.5 \pm 9.5\right.$ spikes; threshold, $\left.39.6 \pm 1.4^{\circ} \mathrm{C}\right)$ compared with WT mice $\left(22.1 \pm 5.7\right.$ spikes; $p>0.1, t$ test; threshold, $38.5 \pm 1.6^{\circ} \mathrm{C}$; $p>0.5, t$ test).

\section{Innervation of hair follicles is reduced in NT4-/- mice}

Some D-hair receptors are thought to terminate on down (vellus) hair follicles (Brown and Iggo, 1967; Burgess et al., 1968; Perl, 1968). Therefore, we determined whether a loss of D-hair receptors in NT4-/- mice could also be observed at the level of innervation of hair follicles. The exact morphology of the periph- 


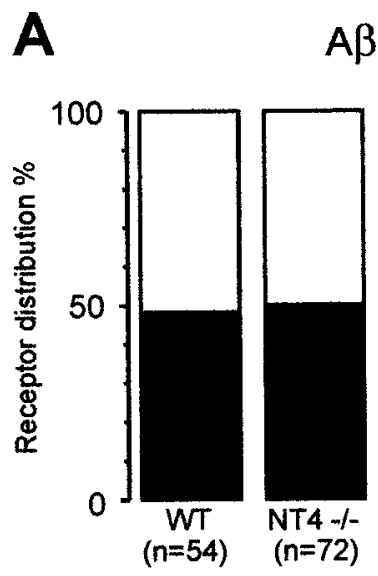

RA
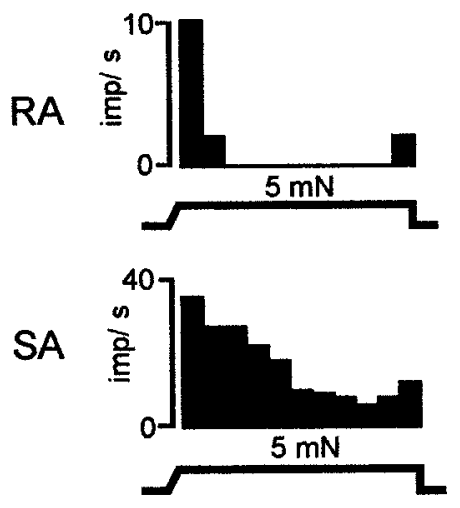

B

SA fibers

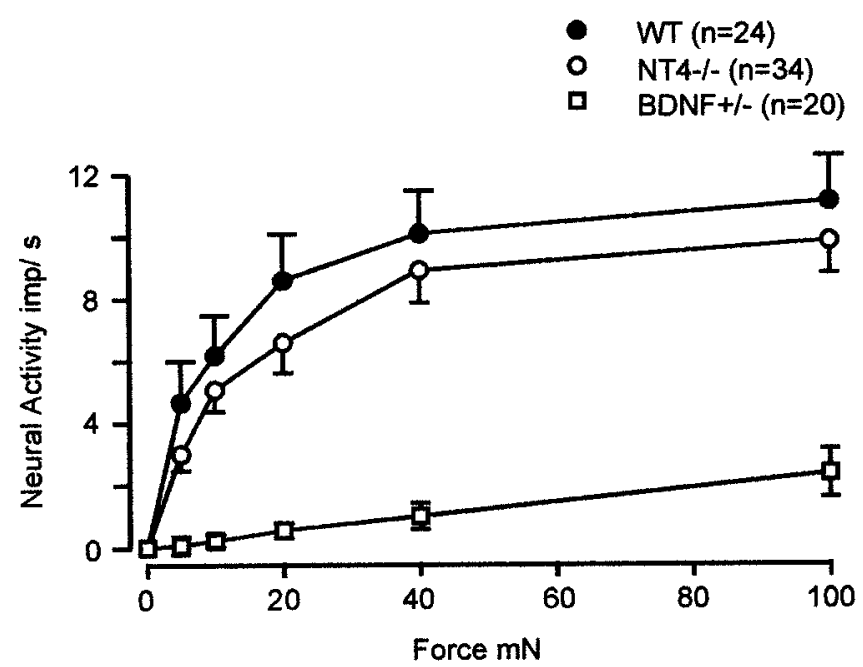

Figure 3. A, Left, Prevalence of subtypes of large myelinated (A $\beta-$ ) cutaneous fibers in WT and NT4-/- mice. Right, Representative examples of the mechanical response properties of an RA fiber (top) and an SA fiber (bottom). B, Stimulus-response functions of SA fibers to constant force stimuli. The stimulus-response functions of SA fibers in NT4-/mice were not different from those of WT mice but differed strikingly from those found in BDNF-knock-out animals (BDNF-KO data from Carroll et al., 1998).

eral endings of D-hair receptors is not known; however, down hair follicles appear to be encircled one or more times by a myelinated fiber (Millard and Woolf, 1988; Payne et al., 1991). Figure $4 A$ shows an example of innervated down hair follicles from a WT animal. Whereas the number of down hair follicles per millimeter of epidermis was not different in NT4-/- mice compared with WT controls, the number of hair follicles that were encircled by myelinated fibers in NT4 $-/-$ mice $(3.4 \pm 0.7)$ was reduced by $40 \%$ compared with WT controls $(5.7 \pm 0.7 ; p<$ $0.05, t$ test; Fig. $4 B$ ). Thus, reduced innervation of down hair follicles by myelinated fibers correlates with the loss of functional D-hair receptors found in the electrophysiological experiments.

\section{DISCUSSION}

Our results demonstrate a novel and specific role for NT4 in supporting a functionally identified subclass of cutaneous sen- sory neurons. Using three independent methods of analysis, we show that NT4 is required for the survival of D-hair receptors. Axon counts in the saphenous nerve of NT4-/- mice revealed a selective loss of small-diameter axons; electrophysiological analysis showed a corresponding loss of functionally defined D-hair receptors; and immunohistochemical analysis of the hairy skin showed reduced innervation of down hair follicles by myelinated fibers. Recent studies in young NT4-/- mice have shown that D-hair receptors are present in normal numbers and have normal response properties until 3 weeks of age (Stucky and Lewin, 1998). This indicates that D-hair receptors develop normally in the embryo and undergo postnatal cell death. By revealing a niche for NT4, these data extend the concept that different members of the neurotrophin family act in a modality-specific way on subclasses of sensory neurons. A previous report of cell counts in the L4 dorsal root ganglia suggested that there is no significant loss of dorsal root ganglion neurons in NT4-/- mice (Liu et al., 1995) and therefore seems to be conflicting with results of the present study. However, the number of D-hair receptors is $<5 \%$ of the total number axons in different nerves innervating the hairy skin of the hindlimb (Airaksinen et al., 1996; Albers et al., 1996) and D-hair afferents are not found in the glabrous skin, which is also innervated by cells in lumbar dorsal root ganglia. Thus, the fact that at most $5 \%$ of the cell bodies in the L4 dorsal root ganglia are D-hair afferents readily explains why a loss in neurons of this small magnitude has passed unnoticed in counts of whole ganglia.

The morphology of the peripheral ending of D-hair receptors is not exactly known (Light and Perl, 1993) but are thought to innervate hairs (Munger and Ide, 1988). Down hair follicles are usually innervated by a myelinated fiber that encircles the base of the follicle (Millard and Woolf, 1988; Payne et al., 1991). Although NT4-/- mice showed a significant loss in the innervation of hair follicles, many follicles were still innervated even though all functional D-hair receptors in NT4-/- mice were gone. The remaining innervation of hair follicles in NT4-/- mice is most likely attributable to innervation by other types of afferent fibers. It is known that other types of cutaneous neurons such as RA fibers, which were normal in NT4-/- mice, also innervate hair follicles (Brown and Iggo, 1967; Perl, 1968).

NT4 is not the only neurotrophin required by D-hair receptors for survival. A previous study demonstrated that mice lacking NT3 have a reduced number of D-hair receptors (Airaksinen et al., 1996), and there is evidence that both factors are required at different periods during development (Stucky and Lewin, 1998). Furthermore, these results provide functional relevance to the fact that many adult sensory neurons that express trkB also express trkC, the high-affinity receptor for NT3 (McMahon et al., 1994).

NT4 binds to two distinct receptors, the high-affinity tyrosine kinase $\mathrm{B}$ receptor and the low-affinity neurotrophin receptor $\mathrm{p} 75$ (Berkemeier et al., 1991; Hallböök et al., 1991; Ip et al., 1992). The receptor responsible for the NT4-dependent survival of $\mathrm{D}$-hair receptors is most likely trkB, because D-hair receptors survive in normal proportions in mice lacking the low-affinity p75 receptor (Stucky and Koltzenburg, 1997). Furthermore, because trkB is expressed by $10-20 \%$ of dorsal root ganglion neurons, most of which have medium to large somata that give rise to myelinated axons (Kashiba et al., 1995; Wetmore and Olson, 1995; Wright and Snider, 1995), the population of sensory neurons that expresses trkB correlates with the population likely to 

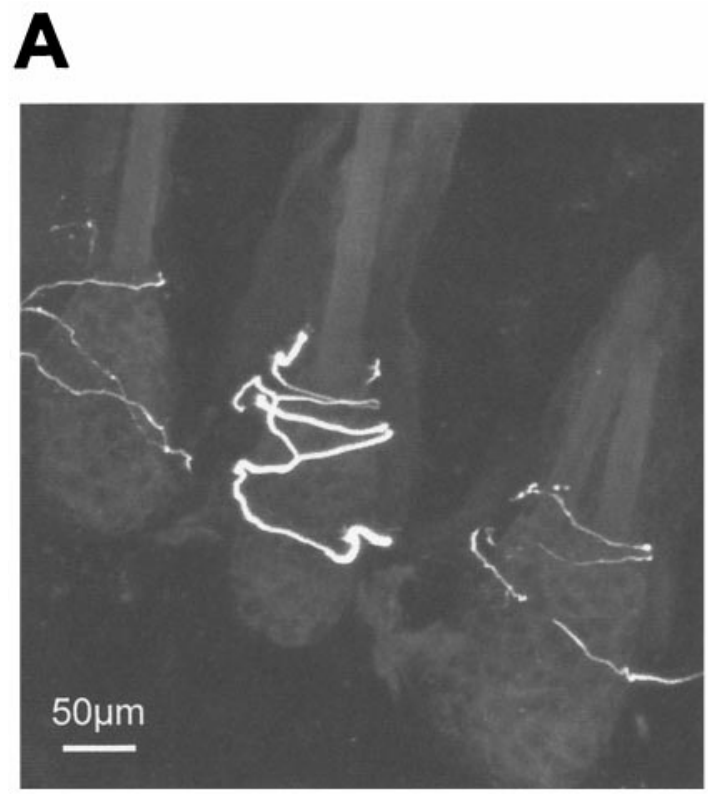

B

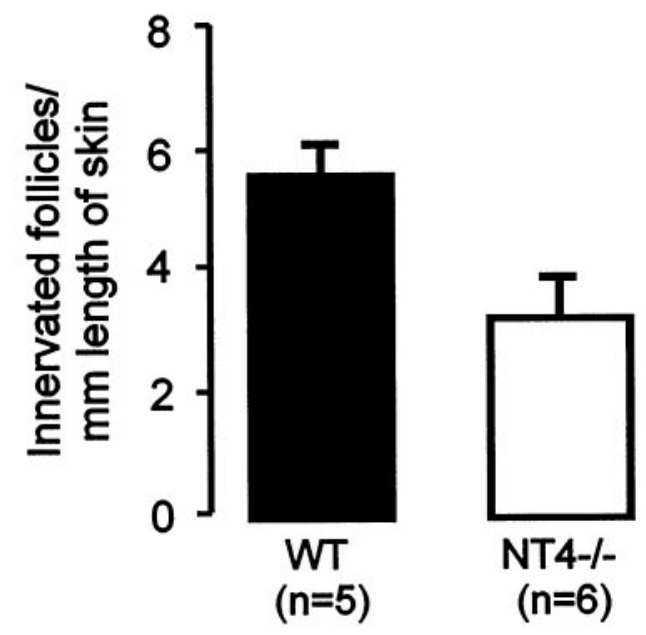

Figure 4. A, Down hair follicles in skin from a WT mouse immunostained with anti-neurofilament antibody. Note the variety in the thickness of the neurofilament-positive fibers. $B$, Mean number of innervated hair follicles per millimeter length of skin in WT and NT4-/ - mice, which was significantly different $(p<0.05, t$ test $)$.

be D-hair receptors. Although p75 is not required for the survival of D-hair receptors, the presence of p75 is necessary for the normal mechanical function of D-hairs, because D-hair receptors in p $75-/-$ mice are impaired in mechanical function (Stucky and Koltzenburg, 1997). Intriguingly, biochemical studies indicate that NT4, but none of the other neurotrophins, requires binding to 75 for efficient activation of trk receptors, suggesting a role for p75 in NT4-trkB signaling (Rydén et al., 1995). Together, these data suggest that NT4 mediates survival of D-hairs via trkB alone, but NT4 requires p75 to confer normal mechanical function to D-hair receptors.

The results of the present study indicate that the two preferred trkB ligands, NT4 and BDNF, have entirely different roles in supporting cutaneous sensory neurons. NT4 is required for the survival of D-hair receptors but not for the mechanical function of SA fibers. Conversely, BDNF is required for the mechanical function of SA fibers but plays no role in the survival of D-hair receptors (Carroll et al., 1998). Thus, not only do NT4 and BDNF affect the survival of different populations of sensory neurons, but they also have physiologically distinct roles. These data are consistent with recent results in visceral sensory neurons where NT4 and BDNF have been shown to support discrete populations of nodose-petrosal neurons (Erickson et al., 1996). Nonoverlapping roles for NT4 and BDNF have also been observed in other types of neurons. In vivo, delivery of NT4 but not BDNF rescues neurons in the lateral geniculate nucleus from monocular deprivation (Riddle et al., 1995) and reverses spatial memory impairments in aged rats (Fischer et al., 1994). In vitro, NT4 but not BDNF promotes the survival of cultured striatal neurons (Ardelt et al., 1994). Conversely, BDNF but not NT4 induces dopamine uptake in neuronal cultures from the ventral mesencephalon (Hyman et al., 1994).

The fact that NT4 and BDNF both bind trkB raises the question of how neurons discriminate between these two ligands. One explanation is that the two neurotrophins may spatially be expressed differently in local target structures. It is known that NT4 and BDNF are expressed in general in the skin (Timmusk et al., 1993), but it is not known whether there is selective expression of NT4 or BDNF in down hair follicles and Merkel cells, the targets of D-hair receptors and SA fibers, respectively. In the whisker pad, however, high levels of NT4 are found at the same time in development that trigeminal neurons begin to innervate hair follicles (Davies et al., 1987; Ibáñez et al., 1993). Another possibility is that NT4 and BDNF may be temporally expressed differently during development when D-hair receptors and SA fibers innervate their targets. In rodents, innervation of Merkel cells in hairy skin begins early, around embryonic day 13 (Pasche et al., 1990), whereas innervation of hair follicles in the hindlimb begins much later at postnatal day 7 (Payne et al., 1991).

Alternatively, D-hair and SA fibers may express different isoforms of the trkB receptor, which may selectively bind NT4 or BDNF, allowing D-hair receptors and SA fibers to distinguish between the two neurotrophins. At least three distinct isoforms of the trkB receptor are expressed by mammalian neurons (Armanini et al., 1995), including two truncated trkB receptors that are also capable of signal transduction (Baxter et al., 1997). Indeed, a recent binding study shows that truncated forms of trkB can differentiate between NT4 and BDNF (Strohmaier et al., 1996). Another possibility is that different accessory molecules may assist a given trkB receptor in discriminating between the two neurotrophins, either at the level of receptor recognition or the level of signal transduction. Interestingly, expression of isoforms of trkB receptors has been shown to be regulated developmentally in that the full-length trkB receptor is expressed early in development, whereas a truncated form of trkB (trkB.T1) is the major isoform expressed in the adult (Allendoerfer et al., 1994; Escandón et al., 1994; Armanini et al., 1995). Therefore, temporal regulation of trkB receptor isoforms is also a possible mechanism 
by which $\mathrm{D}$-hair receptors and SA fibers could discriminate between NT4 and BDNF.

In conclusion, the data presented here demonstrate that NT4 has a novel and specific role in supporting the survival of one class of cutaneous sensory neurons. In the absence of both NT4 alleles, all D-hair receptors undergo cell death. Interestingly, only one functional NT4 allele is required to support the survival of all NT4-dependent nodose-petrosal ganglion neurons (Erickson et al., 1996). Thus, further studies with mice that are heterozygous for deletion of the NT4 gene will determine whether the survival of D-hair receptors depends on only one NT4 allele or both alleles.

\section{REFERENCES}

Airaksinen MS, Koltzenburg M, Lewin GR, Masu Y, Helbig C, Wolf E, Brem G, Toyka KV, Thoenen H, Meyer M (1996) Specific subtypes of cutaneous mechanoreceptors require neurotrophin-3 following peripheral target innervation. Neuron 16:287-295.

Albers KM, Perrone TN, Goodness TP, Jones ME, Green MA, Davis BM (1996) Cutaneous overexpression of NT3 increases sensory and sympathetic neuron number and enhances touch dome and hair follicle innervation. J Cell Biol 134:487-497.

Allendoerfer KL, Cabelli RJ, Escandón E, Kaplan DR, Nikolics K, Shatz CJ (1994) Regulation of neurotrophin receptors during the maturation of the mammalian visual system. J Neurosci 14:1795-1811.

Ardelt AA, Flaris NA, Roth KA (1994) Neurotrophin-4 selectively promotes survival of striatal neurons in organotypic slice culture. Brain Res 647:340-344.

Armanini MP, McMahon SB, Sutherland J, Shelton DL, Phillips HS (1995) Truncated and catalytic isoforms of trkB are coexpressed in neurons of rat and mouse CNS. Eur J Neurosci 7:1403-1409.

Barbacid M (1994) The Trk family of neurotrophin receptors. J Neurobiol 25:1386-1403.

Baxter GT, Radeke MJ, Kuo RC, Makrides V, Hinkle B, Hoang R, Medina-Selby A, Coit D, Valenzuela P, Feinstein SC (1997) Signal transduction mediated by the truncated trkB receptor isoforms, trkB.T1 and trkB.T2. J Neurosci 17:2683-2690.

Berkemeier LR, Winslow JW, Kaplan DR, Nikolics K, Goeddel DV, Rosenthal A (1991) Neurotrophin-5: a novel neurotrophic factor that activates trk and trkB. Neuron 7:857-866.

Brown AG, Iggo A (1967) A quantitative study of cutaneous receptors and afferent fibers in the cat and rabbit. J Physiol (Lond) 193:707-733.

Burgess PR, Petit D, Warren RM (1968) Receptor types in cat hairy skin supplied by myelinated fibers. J Neurophysiol 31:833-848.

Carroll P, Lewin GR, Koltzenburg M, Toyka KV, Thoenen H (1998) A role for BDNF in mechanosensation. Nat Neurosci 1:42-46.

Conover JC, Erickson JT, Katz DM, Bianchi LM, Poueymirou WT, McClain J, Pan L, Helgren M, Ip NY, Boland P, Friedman B, Wiegand S, Vejsada R, Kato AC, DeChiara TM, Yancopoulos GD (1995) Neuronal deficits, not involving motor neurons, in mice lacking BDNF and/or NT4. Nature 375:235-238.

Crowley C, Spencer SD, Nishimura MC, Chen KS, Pitts-Meek S, Armanini MP, Ling LH, McMahon SB, Shelton DL, Levinson AD, Phillips HS (1994) Mice lacking nerve growth factor display perinatal loss of sensory and sympathetic neurons yet develop basal forebrain cholinergic neurons. Cell 76:1001-1011.

Davies AM (1997) Neurotrophin switching: where does it stand? Curr Opin Neurobiol 7:110-118.

Davies AM, Bandtlow C, Heumann R, Korsching S, Rohrer H, Thoenen H (1987) Timing and site of nerve growth factor synthesis in developing skin in relation to innervation and expression of the receptor. Nature 326:353-358.

Erickson JT, Conover JC, Borday V, Champagnat J, Barbacid M, Yancopoulos GD, Katz DM (1996) Mice lacking brain-derived neurotrophic factor exhibit visceral sensory neuron losses distinct from mice lacking NT4 and display a severe developmental deficit in control of breathing. J Neurosci 16:5361-5371.

Ernfors P, Lee KF, Jaenisch R (1994a) Mice lacking brain-derived neurotrophic factor develop with sensory deficits. Nature 368:147-150.

Ernfors P, Lee KF, Kucera J, Jaenisch R (1994b) Lack of neurotrophin-3 leads to deficiencies in the peripheral nervous system and loss of limb proprioceptive afferents. Cell 77:503-512.
Escandón E, Soppet D, Rosenthal A, Mendoza-Ramirez JL, Szonyi E, Burton LE, Henderson CE, Parada LF, Nikolics K (1994) Regulation of neurotrophin receptor expression during embryonic and postnatal development. J Neurosci 14:2054-2068.

Farinas I, Jones KR, Backus C, Wang XY, Reichardt LF (1994) Severe sensory and sympathetic deficits in mice lacking neurotrophin-3. Nature 369:658-661.

Fischer W, Sirevaag A, Wiegand SJ, Lindsay RM, Björklund A (1994) Reversal of spatial memory impairments in aged rats by nerve growth factor and neurotrophins 3 and 4/5 but not by brain-derived neurotrophic factor. Proc Natl Acad Sci USA 91:8607-8611.

Forster C, Handwerker HO (1990) Automatic classification and analysis of microneurographic spike data using a PC/AT. J Neurosci Methods 31:109-118.

Hallböök F, Ibáñez CF, Persson H (1991) Evolutionary studies of the nerve growth factor family reveal a novel member abundantly expressed in Xenopus ovary. Neuron 6:845-858.

Hyman C, Juhasz M, Jackson C, Wright P, Ip NY, Lindsay RM (1994) Overlapping and distinct actions of the neurotrophins BDNF, NT3, and NT4/5 on cultured dopaminergic and GABAergic neurons of the ventral mesencephalon. J Neurosci 14:335-347.

Ibáñez CF (1996) Neurotrophin-4: the odd one out in the neurotrophin family. Neurochem Res 21:787-793.

Ibáñez CF, Ernfors P, Timmusk T, Ip NY, Arenas E, Yancopoulos GD, Persson H (1993) Neurotrophin-4 is a target-derived neurotrophic factor for neurons of the trigeminal ganglion. Development 117:1345-1353.

Ip NY, Ibáñez CF, Nye SH, McClain J, Jones PF, Gies DR, Belluscio L, Le Beau MM, Espinosa R, Squinto SP, Persson H, Yancopoulos GD (1992) Mammalian neurotrophin-4: structure, chromosomal localization, tissue distribution, and receptor specificity. Proc Natl Acad Sci USA 89:3060-3064.

Ip NY, Stitt TN, Tapley P, Klein R, Glass DJ, Fandl J, Greene LA, Barbacid M, Yancopoulos GD (1993) Similarities and differences in the way neurotrophins interact with the Trk receptors in neuronal and non-neuronal cells. Neuron 10:137-149.

Kashiba H, Noguchi K, Ueda Y, Senba E (1995) Coexpression of trk family members and low-affinity neurotrophin receptors in rat dorsal root ganglion neurons. Mol Brain Res 30:158-164.

Klein R, Silos-Santiago I, Smeyne RJ, Lira SA, Brambilla R, Bryant S, Zhang L, Snider WD, Barbacid M (1994) Disruption of the neurotrophin-3 receptor gene trkC eliminates la muscle afferents and results in abnormal movements. Nature 368:249-251.

Koltzenburg M, Stucky CL, Lewin GR (1997) Receptive properties of mouse sensory neurons innervating hairy skin. J Neurophysiol $78: 1841-1850$.

Lewin GR, Barde YA (1996) Physiology of neurotrophins. Annu Rev Neurosci 19:289-317.

Light AR, Perl ER (1993) Peripheral sensory systems. In: Peripheral neuropathy (Dyck PJ, Thomas PK, Griffin JW, Low PA, Poduslo JF, eds), pp 149-165. Philadelphia: Saunders.

Liu X, Ernfors P, Wu H, Jaenisch R (1995) Sensory but not motor neuron deficits in mice lacking NT4 and BDNF. Nature 375:238-241.

McMahon SB, Armanini MP, Ling LH, Phillips HS (1994) Expression and coexpression of Trk receptors in subpopulations of adult primary sensory neurons projecting to identified peripheral targets. Neuron 12:1161-1171.

Millard CL, Woolf CJ (1988) Sensory innervation of the hairs of the rat hindlimb: a light microscopic analysis. J Comp Neurol 277:183-194.

Munger BL, Ide C (1988) The structure and function of cutaneous sensory receptors. Arch Histol Cytol 51:1-34.

Pasche F, Merot Y, Carraux P, Saurat JH (1990) Relationship between Merkel cells and nerve endings during embryogenesis in the mouse epidermis. J Invest Dermatol 95:247-251.

Payne J, Middleton J, Fitzgerald M (1991) The pattern and timing of cutaneous hair follicle innervation in the rat pup and human fetus. Dev Brain Res 61:173-182.

Perl ER (1968) Myelinated afferent fibers innervating the primate skin and their response to noxious stimuli. J Physiol (Lond) 197:593-615.

Riddle DR, Lo DC, Katz LC (1995) NT4-mediated rescue of lateral geniculate neurons from effects of monocular deprivation. Nature 378:189-191.

Rydén M, Murray-Rust J, Glass D, Ilag LL, Trupp M, Yancopoulos GD, 
McDonald NQ, Ibáñez CF (1995) Functional analysis of mutant neurotrophins deficient in low-affinity binding reveals a role for p75LNGFR in NT4 signalling. EMBO J 14:1979-1990.

Smeyne RJ, Klein R, Schnapp A, Long LK, Bryant S, Lewin A, Lira SA, Barbacid M (1994) Severe sensory deficits and sympathetic neuropathies in mice carrying a disrupted Trk/NGF receptor gene. Nature 368:246-249.

Strohmaier C, Carter BD, Urfer R, Barde YA, Dechant G (1996) A splice variant of the neurotrophin receptor trkB with increased specificity for brain-derived neurotrophic factor. EMBO J 15:3332-3337.

Stucky CL, Koltzenburg M (1997) The low-affinity neurotrophin receptor p75 regulates the function but not the selective survival of specific subpopulations of sensory neurons. J Neurosci 17:4398-4405.

Stucky CL, Lewin GR (1998) Neurotrophin-3 and neurotrophin-4 are sequentially required for the survival of D-hair receptors. Forum of European Neuroscience 10:115.

Timmusk T, Belluardo N, Metsis M, Persson H (1993) Widespread and developmentally regulated expression of neurotrophin-4 mRNA in rat brain and peripheral tissues. Eur J Neurosci 5:605-613.

Wetmore C, Olson L (1995) Neuronal and non-neuronal expression of neurotrophins and their receptors in sensory and sympathetic ganglia suggest new intercellular trophic interactions. J Comp Neurol 353:143-159.

Willis WD, Coggeshall RE (1991) Sensory mechanisms of the spinal cord. New York: Plenum.

Wright DE, Snider WD (1995) Neurotrophin receptor mRNA expression defines distinct populations of neurons in rat dorsal root ganglia. J Comp Neurol 351:329-338. 